\title{
Assessment of Arsenic Content in Deep Groundwater of Kathmandu Valley, Nepal
}

\author{
Sushila Gwachha ${ }^{1,2}$, Bishwanath Acharya ${ }^{1,3}$, Agni Dhakal ${ }^{1}$, Sujen Man Shrestha ${ }^{1}$ and \\ Tista Prasai Joshi ${ }^{1 *}$ \\ ${ }^{I}$ Environment and Climate Study Laboratory, Faculty of Science, Nepal Academy of \\ Science and Technology, Lalitpur, Nepal \\ ${ }^{2}$ Department of Environmental Science, Khwopa College, Bhaktapur, Nepal \\ ${ }^{3}$ Thammasat University Chulabhorn International College of Medicine, Pathumthani, \\ Thailand
}

*Corresponding Author

tista.prasai@nast.gov.np

\begin{abstract}
The contamination of groundwater by arsenic is one of the major problems in Nepal. This study was conducted in 20 deep groundwater $(>200 \mathrm{~m}$ ) samples of Kathmandu valley to assess the arsenic content of different groundwater zones and to determine the relationship of arsenic with physicochemical parameters. Samples were collected in the post-monsoon season of 2016. The random sampling method was applied for the collection of water samples. Standard methods as APHA 2005 was followed for the analysis of the water sample. Arsenic concentration showed spatial variation. The maximum concentration of arsenic was found in Central Groundwater Zone at Patan (27040'07.3" and $\left.85^{\circ} 19^{\prime} 14^{\prime \prime}\right)$. Karl Pearson's correlation coefficient revealed that moderate positive correlation of arsenic concentration with electrical conductivity $(\mu \mathrm{S} / \mathrm{cm})(\mathrm{r}=0.58$ and $p=0.01)$ and turbidity $(\mathrm{NTU})(\mathrm{r}=0.67$ and $p=0.01)$. Groundwater consumers of the central zone of the valley are at risk of arsenic-based health issues.
\end{abstract}

\section{Keywords}

Arsenic, deep-groundwater, guideline, spatial variation

\section{Background}

Arsenic (As) is a well-known element found in the Earth's crust. An average of approximately $5 \mathrm{mg}$ / $\mathrm{kg}$ of arsenic is found in soil (Garelick et al., 2009). Rocks associated with geological and geothermal activities are the significant contributors of arsenic. More than 200 mineral deposits contain arsenic (Smedley and Kinniburgh 2002). Human activities like mining, processing of ores, and manufacturing activities using arsenic bearing sulfides are anthropogenic sources of arsenic to the environment.

Arsenic occurs in different oxidation states $(+5,+3,0,-3,-5)$ in environment. In an aqueous environment, it occurs in mostly two states $(+3$ and +5$)$ (Smedley and Kinniburgh 2002).
Arsenic is released into groundwater due to several geochemical processes like oxidations of arsenic bearing sulfides, desorption of arsenic from oxides and hydroxides, and release from geothermal water, leaching of arsenic from sulfide bicarbonates (Nickson et al., 2000). The majority of arsenic contamination of groundwater in the world is geogenic (Mukherjee et al., 2006).

Department of Health and Human Services (DHHS), International Agency for Research on Cancer (IARC), an Environmental Protection Agency (EPA) have classified inorganic arsenic as a potent human carcinogen (USDHHS 2007). Arsenic is known to cause cancer of liver, bladder, lungs, and skin, and non-cancer effects of arsenic include peripheral vascular, cardiovascular, 
cerebrovascular diseases, diabetes, and adverse reproductive outcomes (Brown and Ross 2002; US DHHS 2007). Arsenic +3 is considered more toxic than arsenic +5 (Ratnaike 2003; Yousef et al., 2008). Considering its toxic effects, the level of arsenic allowed in drinking water has been set as $0.01 \mathrm{ppm}$ by the World Health Organization (WHO) and $0.05 \mathrm{ppm}$ by Nepal's drinking water quality standard (NDWQS 2005).

Groundwater contamination by arsenic is considered as one of the most severe problems worldwide (Bhattacharya et al., 2003). Bangladesh, Afghanistan, Argentina, Canada, Cambodia, Myanmar are some of the countries facing the problem of groundwater contamination by arsenic (Mukharjee et al., 2006). In the case of Nepal, groundwater contamination by arsenic is a significant issue of current drinking water supply systems in the Terai region (Thakur et al., 2011). Many shallow tube-well of Nepal contains a higher concentration of arsenic than the safer limit set for drinking purpose (Panthi et al., 2006). The Kathmandu valley contains quaternary sediments similar to those in the Terai, and so the presence of arsenic in the groundwater of Kathmandu valley is suspected (Gurung et al., 2007).

According to Shrestha et al., (2013), 34\% of deep groundwater samples $(n=41)$ of Kathmandu valley exceeded WHO guidelines for arsenic. A similar study conducted by Emerman et al., (2010) found five tube wells out of 6 , and 4 dug wells out of 8 exceeded the WHO guideline of arsenic and geometric mean to be $0.015 \mathrm{ppm}$ for deep groundwater samples. Similarly, JICA/ ENPHO (2005) found that $71.6 \%$ of samples $(n=134)$ exceeded the WHO guideline during the pre-monsoon season, and Chapagain et al., (2009) showed $52 \%$ of the samples $(n=42)$ to exceed WHO guideline.

Drinking water in Kathmandu valley is supplied by Kathmandu Upatyaka Khanepani Limited (KUKL), and the estimated demand in 2016 was 361.6 MLD, with a supply deficit of 210 MLD. This deficit is met through different sources, including groundwater (Udmale et al., 2016). Currently, city supply also uses deep groundwater to meet the demand. Thus, it is possible that city supply drinking water may be contaminated with arsenic,which may cause health problems among the residents of Kathmandu valley.

Hence, this study is carried out to assess the arsenic content in deep groundwater of Kathmandu valley; study the spatial variation of arsenic in different ground water and to determine the relationship of arsenic with physico-chemical parameters. This study provides insight knowledge on arsenic contamination of ground water in Kathmandu valley, which will be useful in mitigation of the problem.

\section{Materials And Methods}

\section{Study Area}

The Kathmandu valley is roughly circular with a diameter of about $25 \mathrm{~km}^{2}$ and an average altitude of $1300 \mathrm{~m}$ (above sea level), located in central Nepal Himalaya within $27^{\circ} 32^{\prime} \mathrm{N}$ to $27^{\circ} 49^{\prime} \mathrm{N}$ and $85^{\circ} 12^{\prime} \mathrm{E}$ to $85^{\circ} 32^{\prime} \mathrm{E}$. Its surrounding hills are approximately 2800 masl. The area of the valley is about $650 \mathrm{~km}^{2}$. The valley comprises of Kathmandu, Lalitpur, and Bhaktapur districts. The Kathmandu valley is an intermontane basin filled with Pliocene quaternary fluvio-lacustrine unconsolidated sediments, which is up to $500 \mathrm{~m}$ thick (Yoshida and Igarashi 1984). Limestones are abundant to the south, whereas to the east and west, phyllites and siltstones border the valley. Granite gneisses are located on the northern border of the valley (Shrestha et al., 1999).

Based on hydrochemical and hydrogeological studies, the deep groundwater of the Kathmandu valley is divided into three groundwater zones Northern Groundwater Zone (NGWZ), Central Groundwater Zone (CGWZ), Southern Groundwater Zone (SGWZ) (JICA 1990). The NGWZ has higher potentialities for recharge of the groundwater and is the principal aquifer in the valley. About $60 \mathrm{~m}$ thick of highly permeable micaceous quartz, sand, and gravel are primary upper deposits of the groundwater district. The upper deposits in the CGWD are covered by impermeable thick stiff black clay, named Kalimati formation, which is rich in organic matter. The groundwater recharge is limited by the presence of the black clay layer in the CGWZ. The significant deposits in the SGWD are thick impermeable clays and basal gravels with low permeability. Conversely, there are sand and 
gravel deposits in some parts of the eastern area of the SGWD, which has a potential for groundwater recharge (Shrestha and Shrestha 2004).

\section{Sample Collection and Analysis}

Altogether 20 water samples were collected from different deep borings of Kathmandu valley; 5 samples from NGWZ, 12 from CGWZ, and four from $\mathrm{SGWZ}$ using a stratified random sampling method. The sampling locations, along with geographical coordinates, are shown in Table 1. The samples were collected in a sterile and sampling bottle of $1000 \mathrm{ml}$, which were acidulated in the ratio of 1:100. Temperature $\left({ }^{\circ} \mathrm{C}\right), \mathrm{pH}$, electrical conductivity $(\mu \mathrm{S} / \mathrm{cm})$, total dissolved solids (TDS) (ppm), and salinity (ppm) were measured at the sampling site with the help of HANNA's multimeter. The samples were transported to the NAST laboratory and stored at
$4{ }^{\circ} \mathrm{C}$ for further analysis. Water quality parameters were analyzed by standard methods as described by APHA (2005). Turbidity (NTU) was measured with HANNA's Nephelometer. Arsenic (ppm), iron $(\mathrm{Fe})(\mathrm{ppm})$, and manganese $(\mathrm{Mn})(\mathrm{ppm})$ were measured by Atomic Absorption Spectrometry (AAS) coupled with hydride generation (AAS Agilent Technologies, 240 FSI flame). Standard solution of arsenic (0.02 ppm, $0.04 \mathrm{ppm}, 0.06$ ppm, and $0.08 \mathrm{ppm})$, manganese ( $0.1 \mathrm{ppm}, 0.5$ $\mathrm{ppm}, 1.0 \mathrm{ppm}$, and $2.0 \mathrm{ppm})$, and iron (1.0 ppm, $2.0 \mathrm{ppm}, 3.0 \mathrm{ppm}$, and $4.0 \mathrm{ppm}$ ) were used for the calibration of the instrument. The instrument's minimum detection limit was $0.01 \mathrm{ppm}$ for arsenic, $0.1 \mathrm{ppm}$ for iron, and $0.05 \mathrm{ppm}$ for manganese. Ammonia $\left(\mathrm{NH}_{3}-\mathrm{N}\right)$ (ppm) was measured with the nesslerization method, and nitrate $\left(\mathrm{NO}_{3}-\mathrm{N}\right)(\mathrm{ppm})$ was measured with the Brucine method with the help of UV spectrophotometer (Jenway).

Table 1. Sampling sites of Kathmandu valley

\begin{tabular}{|c|c|c|c|c|}
\hline \multirow[t]{2}{*}{ SN } & \multirow[t]{2}{*}{ Location } & \multirow[t]{2}{*}{ Symbol } & \multicolumn{2}{|c|}{ GPS Location } \\
\hline & & & Longitude (N) & Latitude (E) \\
\hline 1 & Jhaukhel & NB1 & $27^{0} 40^{\prime} 52.99^{\prime \prime}$ & $85^{0} 25^{\prime} 32.78^{\prime \prime}$ \\
\hline 2 & Bode-2 & NB2 & $27^{0} 41^{\prime} 41.4^{\prime \prime}$ & $85^{0} 23^{\prime} 33^{\prime \prime}$ \\
\hline 3 & Bode-1 & NB3 & $27^{0} 41^{\prime} 41.32^{\prime \prime}$ & $85^{0} 23^{\prime} 46.27^{\prime \prime}$ \\
\hline 4 & Kharipati & NB4 & $27^{0} 41^{\prime} 13.69^{\prime \prime}$ & $85^{0} 27^{\prime} 24.24^{\prime \prime}$ \\
\hline 5 & Jorpati & NB5 & $27^{0} 43^{\prime} 26.3^{\prime \prime}$ & $85^{0} 22^{\prime} 56^{\prime \prime}$ \\
\hline 6 & Durbarmarg & $\mathrm{CB} 1$ & $27^{0} 42^{\prime} 40.8^{\prime \prime}$ & $85^{0} 19^{\prime} 0.2^{\prime \prime}$ \\
\hline 7 & Tripureswor & $\mathrm{CB} 2$ & $27^{0} 41^{\prime} 36.9^{\prime \prime}$ & $85^{\circ} 18^{\prime} 49.8^{\prime \prime}$ \\
\hline 8 & Thapathali & CB3 & $27^{0} 41^{\prime} 26.4^{\prime \prime}$ & $85^{0} 19^{\prime} 12^{\prime \prime}$ \\
\hline 9 & Lainchaur & CB4 & $27^{0} 43 ' 13.9 "$ & $85^{0} 19^{\prime} 8.3^{\prime \prime}$ \\
\hline 10 & Patan-1 & CB5 & $27^{0} 40^{\prime} 07.3^{\prime \prime}$ & $85^{\circ} 19^{\prime} 14^{\prime \prime}$ \\
\hline 11 & Patan-2 & CB6 & $27^{0} 40^{\prime} 07.3^{\prime \prime}$ & $85^{0} 19^{\prime} 14^{\prime \prime}$ \\
\hline 12 & Tahachal & CB7 & $27^{0} 42^{\prime} 06.2^{\prime \prime}$ & $85^{\circ} 17^{\prime} 28^{\prime \prime}$ \\
\hline 13 & Balaju & CB8 & $27^{0} 43^{\prime} 57.1^{\prime \prime}$ & $85^{0} 18^{\prime} 1.2^{\prime \prime}$ \\
\hline 14 & Pepsi-Cola & CB9 & $27^{0} 41^{\prime} 19.8^{\prime \prime}$ & $85^{0} 211^{\prime} 39.5^{\prime \prime}$ \\
\hline 15 & Kalanki-1 & CB10 & $27^{0} 41^{\prime} 47.9^{\prime \prime}$ & $85^{0} 16^{\prime} 35.5^{\prime \prime}$ \\
\hline 16 & Kalanki-2 & CB11 & $27^{0} 46^{\prime} 05.9^{\prime \prime}$ & $85^{0} 18^{\prime} 16.5^{\prime \prime}$ \\
\hline 17 & Matatirtha-1 & SB1 & $27^{0} 40^{\prime} 38.64 "$ & $85^{\circ} 14^{\prime} 20.80^{\prime \prime}$ \\
\hline 18 & Matatirtha-2 & SB2 & $27^{0} 40^{\prime} 37.98^{\prime \prime}$ & $85^{0} 14^{\prime} 24.85^{\prime \prime}$ \\
\hline 19 & Chovar & SB3 & $27^{0} 39^{\prime} 3.89^{\prime \prime}$ & $85^{0} 17^{\prime} 28.12^{\prime \prime}$ \\
\hline 20 & Kirtipur & SB4 & $27^{0} 40 ’ 15.77^{\prime \prime}$ & $85^{\circ} 17^{\prime} 19.75^{\prime \prime}$ \\
\hline
\end{tabular}




\section{Results}

\section{The concentration of arsenic in deep groundwater samples}

The mean arsenic content in the groundwater sample was found to be $0.26 \pm 0.64 \mathrm{ppm}$. Maximum arsenic contents in the different sites are shown in Figures 1 and 2.

Arsenic concentration was found in the sample of Patan hospital-1 (2.8 ppm) followed by Pepsicola $(0.36 \mathrm{ppm})$, and Jorpati $(0.33 \mathrm{ppm})$. Water from well of Patan hospital is being used only for domestic purposes like washing and cleaning but not for drinking purposes. The borewell water from the Pepsi-cola area is being used as a raw material for the production of Pepsi-cola after treatment. They have an advanced water treatment system for purification of iron, ammonia, and other water quality parameters. Water from Jorpati is being used to sell as jar water after treatment. Of the total samples, $76.2 \%$ of samples crossed the WHO guideline of arsenic (0.01 ppm), and 47.6\% of samples crossed Nepal's drinking water quality standard for arsenic (0.05 ppm).

\section{Spatial Variation of Arsenic in different GWZs}

The spatial distribution of arsenic revealed higher values of arsenic in CGWZ.Mean arsenic content in NGWZ, CGWZ, and SGWZ was $0.08 \pm 0.12$ ppm, $0.46 \pm 0.88 \mathrm{ppm}$, and $0.031 \pm 0.023 \mathrm{ppm}$, respectively. Maximum arsenic content was found in CGWZ. Mean arsenic content in all three GWZs was beyond the WHO standard. However, the arsenic content of CGWZ and NGWZ were beyond NDWQS, 2005. The mean arsenic content of SGWZ was within the NDWQS, 2005, as given in Figure 3.

Iron $(\mathrm{Fe})$, manganese $(\mathrm{Mn})$, nitrate $\left(\mathrm{NO}_{3}-\mathrm{N}\right)$, and ammonia $\left(\mathrm{NH}_{3}-\mathrm{N}\right)$, the associated chemical parameters were also evaluated. The mean $\mathrm{Fe}$ was found to be $6.5 \pm 7.9 \mathrm{ppm}$. $70 \%$ of samples were found to contain $\mathrm{Fe}$ beyond the WHO guideline. The mean $\mathrm{Mn}, \mathrm{NO}_{3}-\mathrm{N}$, and $\mathrm{NH}_{3}-\mathrm{N}$ were found to be $4.7 \pm 4.6 \mathrm{ppm}, 13.1 \pm 35.6 \mathrm{ppm}$, and $25.2 \pm 25.5 \mathrm{ppm}$, respectively. Iron and manganese concentrations of $70 \%$ of water

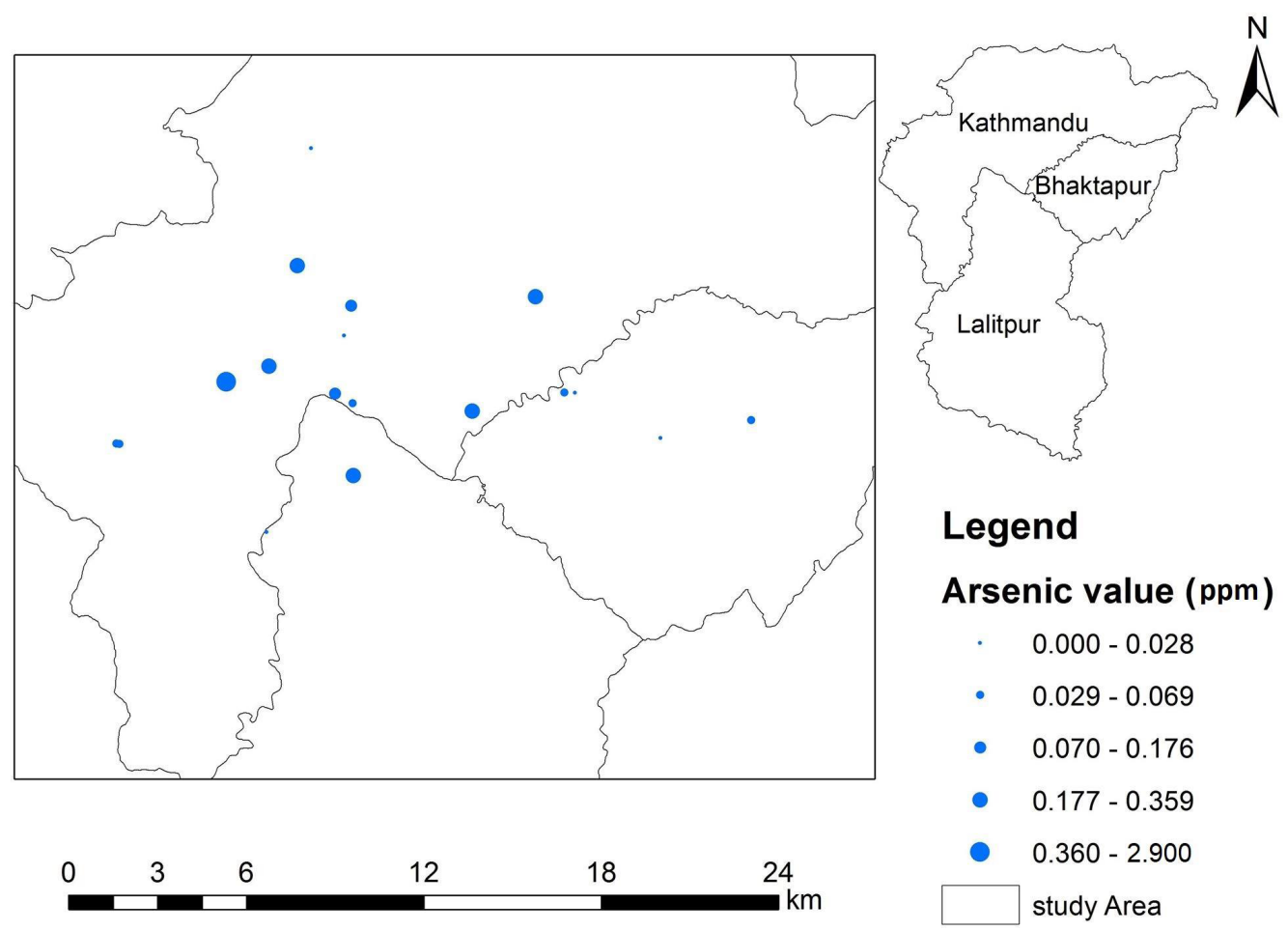

Fig. 1. Map showing sampling locations and their respective arsenic content. 


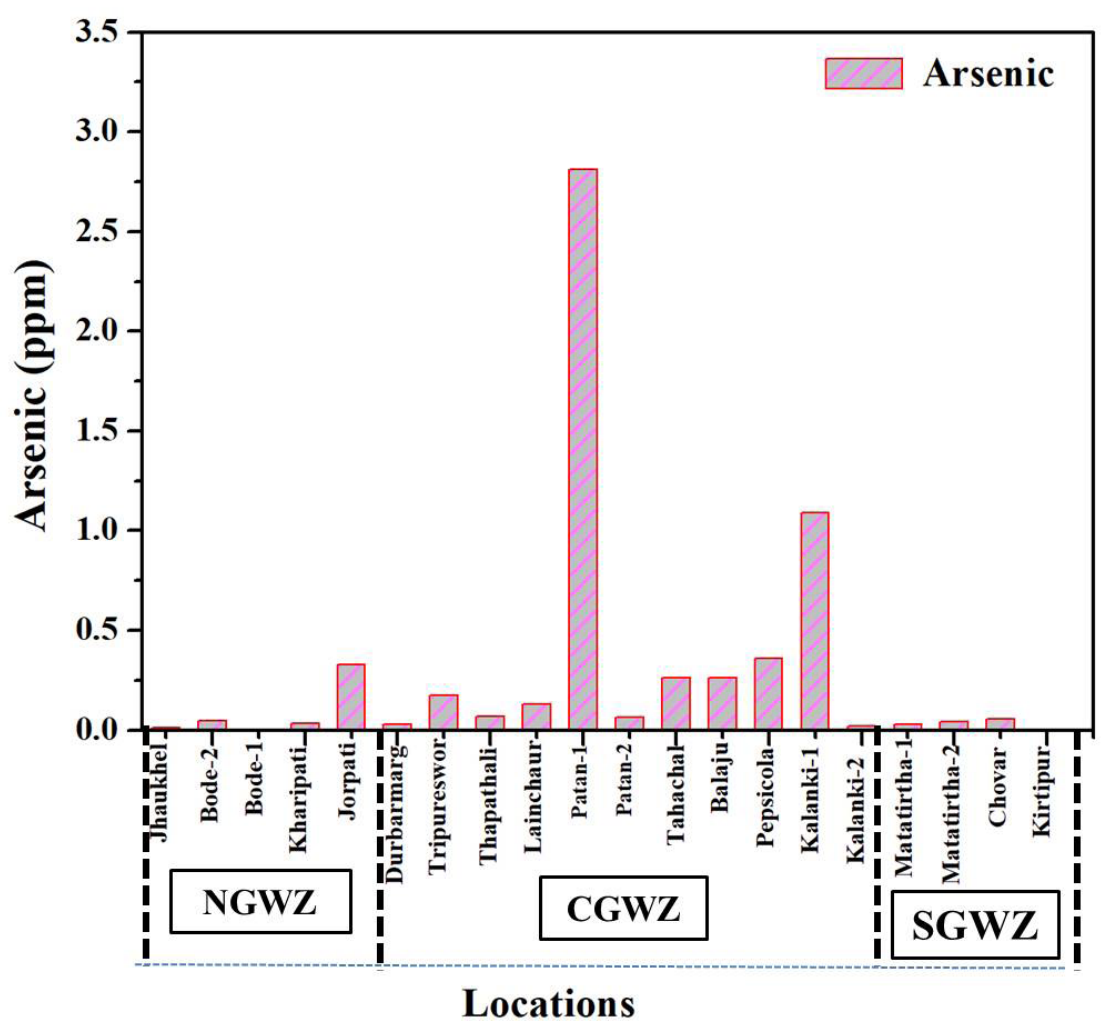

Fig. 2. Concentration of arsenic in deep groundwater samples

samples were found higher than WHO guidelines value (Fe-0.3 ppm and Mn $0.2 \mathrm{ppm})$. However, only $5 \%$ of samples revealed higher $\mathrm{NO}_{3}-\mathrm{N}$ concentration than WHO guideline (50 ppm). We found ammonia was common contaminant for groundwater in Kathmandu valley. Almost $90 \%$ of samples had higher concentration of $\mathrm{NH}_{3}-\mathrm{N}$ than WHO guideline value (1.5 ppm). The mean values of the physicochemical measurements of three groundwater zones is shown in Table 2.

\section{Correlation between arsenic and other parameters}

Karl Pearson's correlation coefficient was used to determine the relationship of arsenic with physicochemical parameters of water $(\mathrm{pH}$, Electrical conductivity (EC), TDS, salinity, turbidity, $\mathrm{Fe}, \mathrm{Mn}, \mathrm{NO}_{3}-\mathrm{N}$, and $\mathrm{NH}_{3}-\mathrm{N}$ ). Arsenic showed significant moderate degree of correlation with electrical conductivity $(\mathrm{r}=0.58, p=0.01)$ and turbidity $(\mathrm{r}=0.67, p=0.02)$. The correlation of arsenic with other parameters was found to be insignificant statistically.

\section{Discussion}

Arsenic contamination in ground water of Nepal was thought to be confined in southern plain of Terai region. However, underground geo-composition of Kathmandu valley suggests leaching of arsenic in its ground water aquifer. This study hypothesized that ground water of Kathmandu valley is also contaminated with arsenic in different aquifer zones. Although previous studies Khatiwada et al., (2002); JICA/ENPHO (2005); Gurung et al., (2006); Bajracharya et al., (2007); Warner et al., (2008); Chapagai et al., (2009); Maharjan et al., (2006); Emerman et al., (2010); Kurosawa et al., (2013); Shrestha et al., (2013); and Koju et al., (2014) have reported occurrence of arsenic in groundwater of Kathmandu valley, however spatial variation of arsenic concentration in different zones is not clear. 


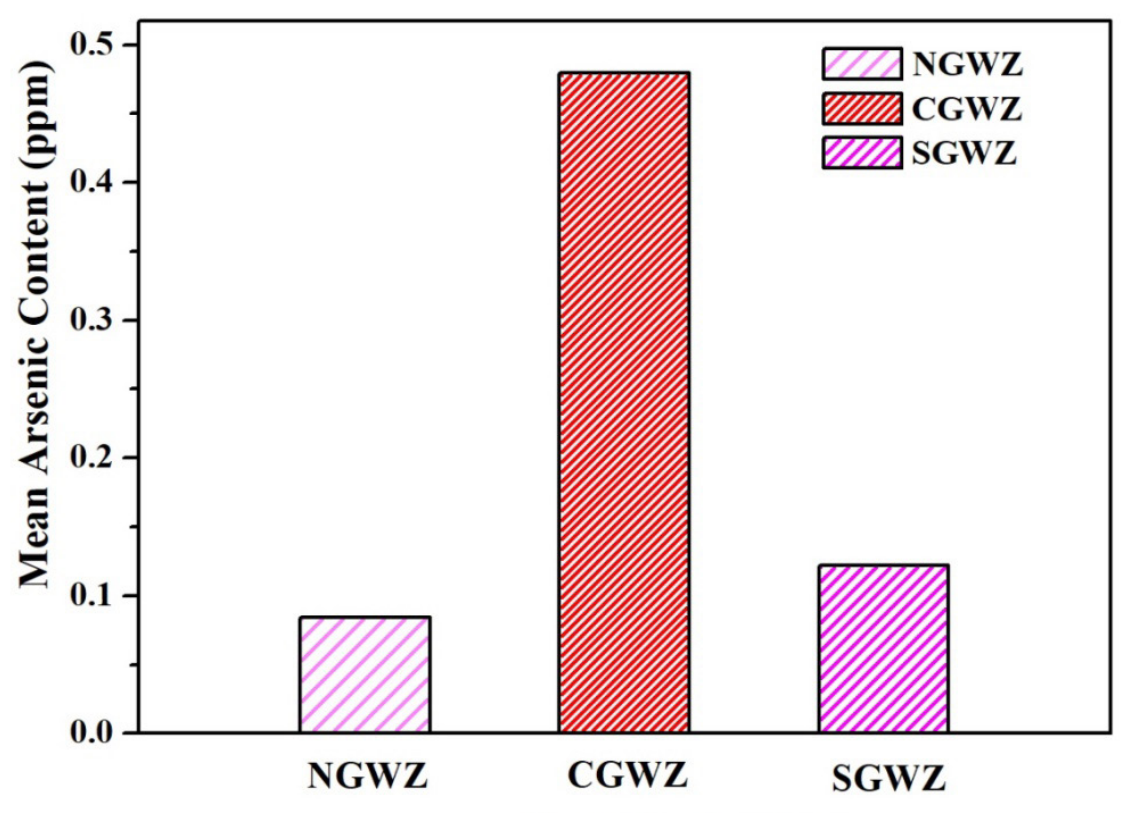

Groundwater Zones

Fig. 3. Variation of arsenic concentration in different GWZs

This study showed that of the total samples $(n=20)$, $76.2 \%$ of samples crossed the WHO standard of arsenic $(0.01 \mathrm{ppm})$, and $47.6 \%$ of samples crossed Nepal's drinking water quality standard for arsenic (0.05 ppm). JICA/ENPHO (2005) also showed that $71.6 \%$ of samples $(n=134)$ exceeded WHO guidelines of arsenic in the pre-monsoon season. Studies by Emerman et al., (2010) and Shrestha et which almost agrees with the result of Emerman et al., (2010) (arsenic: 2.07ppm). This concentration record is the highest to date. All other studies showed arsenic concentration below thislevel. This study showed the mean arsenic content to be 0.26 ppm, which is the same as shown by Maharjan et al., (2006). Mean arsenic concentration, according to Emerman et al., (2010), is $0.015 \mathrm{ppm}$; according

Table 2: Mean of the associated physio-chemical parameter of water sample

\begin{tabular}{llllllllll}
\hline $\begin{array}{l}\text { Param- } \\
\text { eters/ } \\
\text { GWZs }\end{array}$ & $\mathbf{p H}$ & $\begin{array}{l}\text { Electrical } \\
\text { conductivi- } \\
\text { ty }(\boldsymbol{\mu S} / \mathbf{c m})\end{array}$ & $\begin{array}{l}\text { TDS } \\
(\mathbf{p p m})\end{array}$ & $\begin{array}{l}\text { Salinity } \\
(\mathbf{p p m})\end{array}$ & $\begin{array}{l}\text { Turbidity } \\
(\mathbf{p p m})\end{array}$ & $\begin{array}{l}\mathbf{F e} \\
(\mathbf{p p m})\end{array}$ & $\begin{array}{l}\mathbf{M n} \\
(\mathbf{p p m})\end{array}$ & $\begin{array}{l}\mathbf{N O}_{3}-\mathbf{N} \\
(\mathbf{p p m})\end{array}$ & $\begin{array}{l}\mathbf{N H}_{3}-\mathbf{N} \\
(\mathbf{p p m})\end{array}$ \\
\hline NGWZ & $6.6 \pm 0.5$ & $641.2 \pm 680$ & $224.0 \pm 145$ & $0.2 \pm 0.1$ & $13.9 \pm 12.7$ & $3.0 \pm 2.2$ & $3.9 \pm 2.4$ & $2.4 \pm 1.5$ & $34.6 \pm 31.6$ \\
CGWZ & $7.1 \pm 0.6$ & $781.9 \pm 557$ & $297.1 \pm 197$ & $0.4 \pm 0.3$ & $81.9 \pm 105.2$ & $7.3 \pm 6.8$ & $5.1 \pm 5.0$ & $21.6 \pm 50.2$ & $25.7 \pm 27.1$ \\
SGWZ & $7.1 \pm 0.4$ & $332.0 \pm 205$ & $235.0 \pm 146$ & $0.2 \pm 0.1$ & $130.9 \pm 148.4$ & $9.1 \pm 13.9$ & $4.5 \pm 6.6$ & $7.4 \pm 2.4$ & $12.1 \pm 0.4$ \\
\hline
\end{tabular}

al., (2013) showed that $33.33 \%(\mathrm{n}=27)$ and $34 \%$ of samples $(\mathrm{n}=41)$ exceeded WHO guidelines, respectively. According to Koju et al., (2014), $0.4 \%$ of deep borings $(n=287)$ crossed the WHO limit for arsenic. The maximum concentration of arsenic recorded according to this study is $2.8 \mathrm{ppm}$, to Gurung et al., (2006), it is 0.19 ppm, whereas according to Shrestha et al., (2013), it is $0.14 \mathrm{ppm}$. These differences may be due to differences in sampling time.

Arsenic concentration varied spatially. The highest 
concentration was found in CGWZ in comparison to SGWZ and NGWZ. Similar studies conducted by JICA/ENPHO (2005), Chapagain et al., (2009); Gurung et al., (2007); and Shrestha et al., (2013) also showed higher concentration of arsenic in CGWZ. However, Emerman et al., (2010) did not show arsenic's clustering in wells of Kathmandu valley.

There are different models by different researchers for arsenic mobilization in groundwater. Emerman et al., (2010) suggested that losing streams with high arsenic content due to rapid erosion by a combined action of monsoon, deforestation, and tectonic upliftment is the primary cause of high arsenic in groundwater of Kathmandu valley. In contrast, Gurung et al., (2007), Chapagain et al., (2009) and Shrestha et al., (2013) showed evidence of a negative correlation between arsenic and Oxidation Reduction Potential (ORP) and focused on the reductive dissolution mobilization of arsenic. Nickson et al., (2002) and Mc Arthur et al., (2001) suggested that organic matter play a crucial role in arsenic mobilization and Kurowasa et al., (2013) have indicated that the fluvio- lacustrine sediments in the Kathmandu valley are rich in organic matter, mainly the clayey sediments of the central part of the valley which could have enhanced the arsenic mobilization. According to this study, the clustering of arsenic in the CGWZ might have indicated that geological reason is responsible for its occurrence in groundwater of Kathmandu valley.

This study showed significant moderate degree of correlation with electrical conductance $(\mathrm{r}=0.58, p=0.01)$ and turbidity $(\mathrm{r}=0.67, p=$ 0.02). Shrestha et al., (2013) also showed a strong positive correlation between arsenic and EC. Correlation of arsenic with $\mathrm{Fe}, \mathrm{Mn}, \mathrm{NH}_{3}-\mathrm{N}, \mathrm{NO}_{3}-\mathrm{N}$, $\mathrm{pH}$ was found to be insignificant. A similar study by Kurosawa et al., (2013) showed a positive and significant correlation between arsenic and $\mathrm{NH}_{3}-\mathrm{N}$ content. An inverse relation between arsenic and $\mathrm{NO}_{3}-\mathrm{N}$ was established by Gurung et al., (2007), providing evidence for the reductive dissolution model for arsenic mobilization and anaerobic conditions in the deep groundwater.

Despite limited number of samples analyzed in this study, the results clearly indicated there is definite variation in arsenic concentration in different ground water zones, and the arsenic contamination is dependent on turbidity and EC of water. However, seasonal variation and depth of aquifer may also influence the concentration of arsenic, which was not considered in this study. The long term surveillance of ground water parameters is anticipated to understand the dynamics of ground water contaminants.

\section{Conclusion}

This study revealed high concentration of arsenic in deep groundwater of Kathmandu valley. Mean arsenic content was found to be $0.26 \mathrm{ppm}$. This value is higher than the WHO guideline of arsenic for drinking water. In general, this implies that the deep groundwater is not suitable for drinking purposes in terms of arsenic content. A spatial variation of arsenic was found. The highest arsenic concentration was found in the CGWZ, showing the unequal distribution of arsenic in the deep groundwater. The arsenic contamination was moderately correlated with turbidity and EC of water. We recommend that long term monitoring of ground water parameters is required to understand the dynamics of ground water contaminants.

\section{Acknowledgment}

Authors acknowledge Nepal Academy of Science and Technology (NAST) for the laboratory facilities. The authors are thankful to Groundwater Resource Management Committee, Kathmandu for deep ground water data.

\section{References}

APHA. 2005, Standards methods for the examination of water and wastewater $21^{\text {th }}$ Edition. American Public Health Association, American Water Works Association, Water Pollution Control Federation. Published by the American Public Health Association, Washington DC. The USA.

Bajracharya, A. M., Yami, KD, T. Prasai, T., Basnyat, S.R., and Lekhak, B. 2007. Assessment of drinking water quality of Kathmandu Metropolitan areas. Nepal Journal of Science and Technology 8 :133118.

Bhattacharya, P., Tendulkar, N., Neku, A., Aarero 
A., Mukherjee, A., and Jacks, G. 2003. Geogenic arsenic in groundwaters from the Terai alluvial plain of Nepal. Journal of Physics 4:173-176.

Chapagain, S.K.,Shrestha, S., Nakamura, T., Kazama, F.2009. Chemical characteristics of groundwater of Kathmandu valley, Nepal. In: Takizawa, S., Kurisu, F., Satoh, H.Southeast Asian Water Environment 3: 87-93.

Emerman, S. H., Prasai, T. R.B. Anderson, R.B., and Palmer, M.A., 2010. Arsenic contamination of groundwater in Kathmandu valley, Nepal, as a consequence of rapid erosion. Journal of Nepal geological society 40:49-60.

ENPHO, JICA. 2005. Arsenic vulnerability in groundwater resources in Kathmandu valley. Final Report, Kathmandu: Japan International Cooperation Agency (JICA) and Environment and Public Health Organization (ENPHO).

Garelick, H., Jones, H., Dybowska, A., and ValasamiJones, E., 2009. Arsenic pollution sources. Reviews of Environmental Contamination 197:17-51.

Gurung, J.K., Ishiga, H., Khadka, M.S., and Shrestha, N.R. 2007.Characterization of groundwater in the reference of arsenic and nitrate mobilization, Kathmandu basin, Nepal.

JICA. 1990. Groundwater management project in Kathmandu valley. Final Report to Nepal water Supply cooperation, Kathmandu: Japan International Cooperation Agency (JICA).

Khatiwada, N.R., Takizawa, S., Tran, T.V.N., and Inoue, M. 2002. Groundwater contamination assessment for sustainable water supply in Kathmandu valley, Nepal. Water Science and Technology 46:147-154.

Koju, N.K., Prasai, T., Shrestha, S.M., and Raut, P. 2014. Drinking water quality of Kathmandu valley. Nepal Journal of Science and Technology 15:115-120.

Kurosawa, K., Egarshiro, E., and Tani, M. 2013. Relationship of Arsenic with ammoniumnitrogen concentration, oxidation-reduction potential, and $\mathrm{pH}$ of groundwater in the arsenic-contaminated area in Asia, Physics, and Chemistry of the Earth. $\mathrm{A} / \mathrm{B} / \mathrm{C}$ 5860:85-88.

Maharjan, M., Shrestha, B.R., Shrestha, K.B., Shrestha, R.R., Raut (Khadka), R., Kafle, B. and H.Ishihara, H. 2006. Arsenic contamination in groundwater resources in Kathmandu valley. $4^{\text {th }}$ International Symposium on Southeast Asian Water Environment, Bangkok.

Mukherjee, A., Sengupta, M.K., Hossain, M.A., Ahamed, S., Nayak, B., D.Lodh,D., Das, B. Rahman, MM, and Chakraborti, D. 2006. Arsenic contamination in groundwater: A Global perspective with emphasis on Asian scenario. Journal of Health, Population and Nutrition 24:142-163.

Nickson, R.T., McArthur, J. M., Ravenscroft, P., Burgress, W. G. and Ahamed, KM 2000. Mechanism of arsenic release to groundwater, Bangladesh and West Bengal, Applied geochemistry 15:403-413.

Panthi, S. R., Sharma, S., and Mishra, A.K., 2006. Recent status of arsenic contamination in groundwater of Nepal: A Review. Kathmandu University Journal of Science, Engineering, and Technology 2:1-11.

Ratnayake, R. N., 2003. Acute and chronic Toxicity. Postgraduate Medical Journal 79:391-396.

Shrestha, B. R., and Shrestha, K.B., 2004. Spatial distribution of arsenic concentration in groundwater in the Terai, Nepal, In Kansakar, D. R. (ed.), Arsenic Testing and Finalization of Groundwater Legislation Project. Summary Project Report, Lalitpur, Nepal. HMG/ Nepal, Department of Irrigation 85-96.

Shrestha,O.M.,Koirala, A., Karmacharya, S.L., Pradhananga, U.B., Pradhan, and, R. and Karmacharya, R.1999. Engineering and environmental, geological map of the Kathmandu valley $(1: 50,000)$. Department of Mines and Geology, Nepal.

Shrestha, S.M., Rijal, K., and Pokhrel, M.R. 2013. Arsenic contamination in deep and shallow groundwater of Kathmandu valley.Scientific World 11: 25-31. 
Shrestha, R.K., Regmi, D. and Kafle, B.P. 2013. Seasonal variation of arsenic in groundwater of Nawalparasi district of Nepal, International Journal of Applied Science and Biotechnology 2:59-63.

Smedley, P.L. and Kinniburgh, DG 2002. A review of the sources, behavior, and distribution of arsenic in natural waters. Applied geochemistry 17:517-568.

Thakur, J.K., Thakur, K.R., Ramanathan, A., Kumar, M. and Singh, S.K. 2011. Arsenic contamination of groundwater in Nepal- An Overview, Water 3:1-20.

Udmale, P., Ishidaira, H., Thapa,BR, and Shakya, NM, 2016. The status of domestic water demand: supply deficit in the Kathmandu Valley, Nepal. Water 8:196.

US DHHS, 2007. Toxicological Profile for
Arsenic. United States Department of Health and Human Services, Public health services. Agency for toxic substances and disease registry.

Warner, N.R., Levy,J., Harp, K., and Farruggia, F. 2008. Drinking water quality in Nepal's Kathmandu valley: A survey and assessment of selected controlling site characteristics. Hydrological Journal 16:321-334.

Yoshida, M., and Igarashi, Y. 1984. Neogene and quaternary lacustrine sediments in the Kathmandu valley, Nepal. Nepal Geological Society 4:73-100.

Yousef M. I., ElDemerdash F.M. and Radwan F.M.E. 2008, Sodium arsenite-induced biochemical perturbations in rats: Ameliorating effect of curcumin. Food and Chemical Toxicology 46; 3506-3511. 